\title{
Calculation of Rare Earth Element Patterns in Magmatic Fluids: Evidence for Origin of the Lake George Sb-Au-W-Mo Ore Deposit, New Brunswick, Canada
}

\author{
Xue-Ming Yang ${ }^{*} \S$
}

Department of Earth Sciences, University of New Brunswick, P.O. Box 4400, Fredericton, NB, E3B 5A3, Canada

\begin{abstract}
This contribution illustrates the procedures of calculating rare earth element (REE) patterns of magmatic fluids in equilibrium with granitic melts. These patterns can then be compared to those of altered and (or) mineralized rocks in order to investigate the source of the ore-fluids. This technique is applied to the Lake George Sb-Au-W-Mo mineral deposit, New Brunswick, Canada. The results suggest that ore-fluids are dominated by magmatic fluids, consistent with the origin of intrusion-related mineralization systems. The magmatic hydrothermal fluids emanating from progressively cooling, voluminous and volatile-saturated magma at depth may have reacted with earlier magmatic sulphide minerals formed by liquation in the Lake George granodiorite stock, scavenged ore components (e.g., Au, S) in the sulphides, which would have enhanced ore materials in the ore-fluids and precipitated ore minerals in hydrofractures and preexisting faults that crosscut graphitic country rocks (e.g., greywacke) within the metamorphic halos and resulted in intrusion-related gold-antimony mineralization associated with an earlier W-Mo-( $\mathrm{Au})$ mineralization.
\end{abstract}

Keywords: Rare earth element (REE) patterns, partition coefficients, granitoid, intrusion-related gold system, Lake George.

\section{INTRODUCTION}

For simplicity, granitoid is used as a general term for granitic melt crystallized during cooling. During crystallization, a magmatic volatile (or vapour) phase (MVP) is lost to surrounding country rocks. Up to $5 \mathrm{wt} \%$ water dissolved in the magma may have been lost during the solidification process [1]. This magmatic fluid may contain a significant amount of various metals; if precipitated in a suitable geological site(s), a mineral deposit may form. Experimental and empirical investigations of element partitioning between the MVP and granitic melt have made it possible to simulate the composition of MVP [2-4]. These data can be used to compare with observed geochemical data of ore deposits and associated altered rocks, which may provide a key clue as to the contribution of ore-forming materials originating from the magmas or intrusions.

This paper presents the procedures of calculating REE patterns of MVPs on the basis of published experimental partition coefficient data. As a case study, this technique is applied to tracing the REE patterns of magmatic fluids associated with the Lake George granodiorite, which is then compared with altered quartz-feldspar porphyry that host mineralization. Detailed calculation procedures together with a spreadsheet are provided, so that similar computation may be performed for other deposits.

*Address correspondence to this author at the Department of Earth Sciences, University of New Brunswick, P.O. Box 4400, Fredericton, NB, E3B 5A3, Canada; Tel: 1-204-945-6555; Fax: 1-204-945-1406;

E-mail: eric.yang@gov.mb.ca

\$Present address: Manitoba Geological Survey, 360-1395 Ellice Avenue, Winnipeg, MB, R3G 3P2, Canada

\section{PARAMETER SELECTION}

The context of element partition coefficient between MVP and silicate melt used in this study is the same as that suggested by $[5,6]$. REE partition coefficient $\left(k_{p}^{R E E}\right)$ between MVP and silicate melt is defined as: ppm REE concentration in vapour phase divided by $\mathrm{ppm}$ REE concentration in silicate melt. Similarly, chlorine partition coefficient $\left(k_{p}^{C l}\right)$ is defined as: ppm chlorine content in vapour phase divided by ppm chlorine content in silicate melt. It is noted that partition coefficient is dimensionless, and is controlled by the pressure, temperature, and composition of magmatic-hydrothermal systems in question [1-9]. In addition, the value of $k_{p}^{E u}$ may be a function of oxygen fugacity of the system, because Eu has two valences, i.e., $\mathrm{Eu}^{3+}, \mathrm{Eu}^{2+}$, depending $f\left(\mathrm{O}_{2}\right)$ [5].

REE concentration of melt is represented by the data of fresh bulk-rock analysis; REE data of altered rocks are considered to represent the result of the fresh rock reacting with or superimposed by MVPs. If this assumption is true, the signature of MVPs may be identified.

\section{CALCULATION PROCEDURES}

A spreadsheet program is compiled to carry out the calculation, which is available upon a request of the author. Detailed procedures of calculation are described as follows step by step, and an example of the calculation is presented in Table 1.

- $\quad$ Calculate the chlorine molarity $\left(m_{C l}^{m}\right)$ of granite melt that is based on chlorine content of granite or based on the methods by [4], although it is difficult to acquire chlorine concentration in granite melt [10]. 
Table 1. Calculation of REE Concentrations in Magmatic Volatile Phases

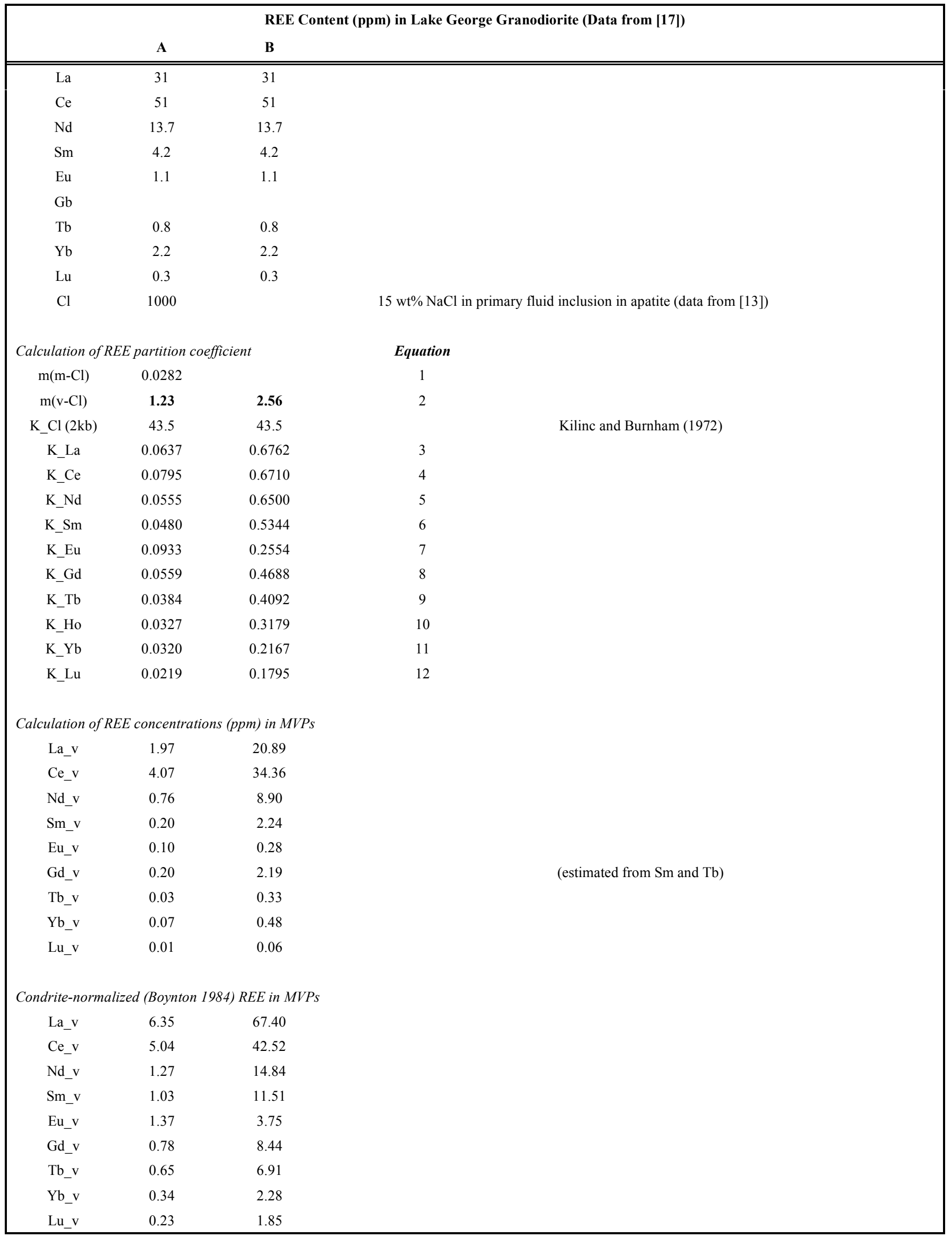




$$
\begin{aligned}
m_{C l}^{m}= & (\text { chlorinecontent } \div 35.5) \times \\
& {[1000 \div(100-\text { chlorinecontent })] }
\end{aligned}
$$

where chlorine content (in whole-rock sample) unit is $\mathrm{wt} \%$.

Using this formula (eq. 1), chlorine molarity of the sample (granite) is calculated. This chlorine molarity is assumed to represent a minimum value of the corresponding granitic melt from which the granite solidified, because much chlorine may have been lost $[1,8]$ due to high chlorine partition coefficient between magmatic volatile phase and silicate melt at magmatic conditions $[5,10-12]$.

Using the methods of Piccoli and Candela [4], a more accurate chlorine molarity of granite melt may be achieved. Their methods require chemical composition data of apatite, or bulk composition of aplite associated with the main intrusion. Here, for simplicity estimated chlorine molarity of granite melt is computed only based on the chlorine content of the studied samples by using eq. 1, which would provide a minimum value for chlorine molarity of granite melt in question.

- Calculate the chlorine molarity $\left(m_{C l}^{v}\right)$ of aqueous vapour phase in equilibrium with the granite melt at magmatic P-T conditions in terms of chlorine partition coefficient $\left(k_{p}^{C l}\right)[5,7]$. The calculation can be made by using the following equation if, $m_{C l}^{m}$ on the basis of Step 1 is given above (see column B in Table 1).

$m_{C l}^{v}=k_{p}^{C l} \times m_{C l}^{m}$

Kilinc and Burnham [5] reported chlorine partition coefficients between chloride-bearing fluids and granitic melts (composition ranging from granite to granodiorite and trondhjemite) under pressure of 2 to $8 \mathrm{~kb}$ and near 700 and $750^{\circ} \mathrm{C}$ isotherms. Their data show that the values of $k_{p}^{C l}$ are strongly pressure dependent, increasing from 43.5 at $2 \mathrm{~kb}$ to 83.3 at 6 $\mathrm{kb}$, and then decreasing sharply to 13.0 at $8 \mathrm{~kb}$. A similar result was reported by [7] for the pressure range of 2 to $4 \mathrm{~kb}$; Webster et al. [7] noticed that the fluorine-free system exhibits higher values of $k_{p}^{C l}$. These results suggest that chlorine partitions strongly in favour of aqueous fluids under magmatic conditions, although some pressure effects were also observed. However, for haplogranite melts containing high fluorine $(>7 \mathrm{wt} \%)$ and low chlorine $(0.12 \mathrm{wt} \%)$ at $2 \mathrm{~kb}$ and $1000^{\circ} \mathrm{C}$, chlorine partitions in favour of the granite melt [7]. So far, there has not been a report that a natural granitic melt (magma) to contain such anomalously high fluorine as shown in that experiment [7].

Also, using the salinity data of fluid-inclusions to estimate the molarity of chlorine may be a quick solution for estimation of $m_{C l}^{v}$, if the fluid-inclusions trapped in minerals represents the primary magmatic aqueous phase in equilibrium with the granite magma. The salinity of primary fluid inclusions trapped in apatite enclosed in a plagioclase crystal (Fig. 1) from a granodiorite sample is a good example of the type of fluid inclusions suitably recommended to use to estimate chlorine molarity of magmatic fluid [13], as shown in column B of Table $\mathbf{1}$.

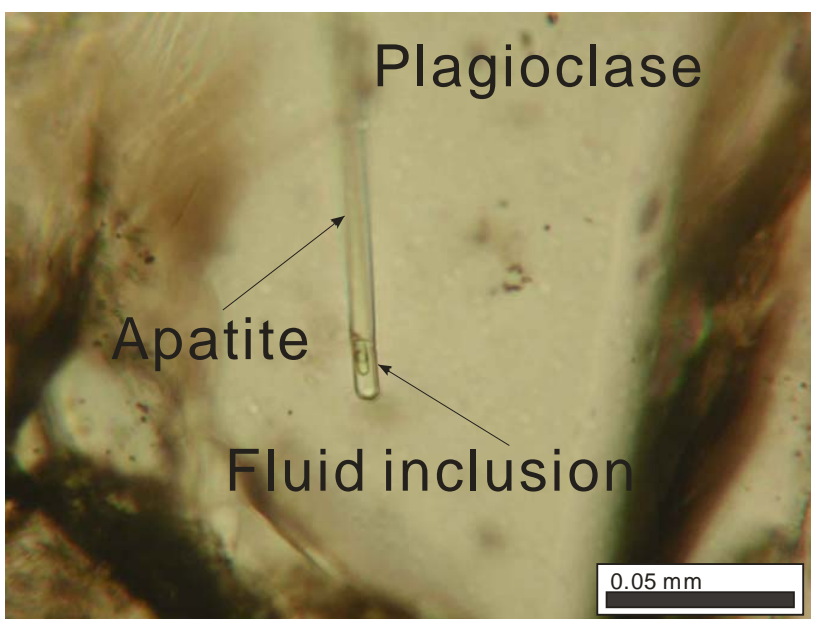

Fig. (1). Primary fluid inclusion trapped in an acicular apatite crystal enclosed in plagioclase grain from the Lake George granodiorite. This inclusion is comprised of liquid and gas phases, and has salinity of $15.0 \% \mathrm{NaCl}_{\text {equiv }}$. Data from [13].

Webster and Holloway [7] showed that fluorine partitions strongly into a granitic melt relative to an aqueous fluid phase, and $k_{p}^{F}$ increases with increasing fluorine in the melt with $<7 \mathrm{wt} \%$ fluorine. If a topaz rhyolite melt contains $\geq 7 \mathrm{wt} \%$ fluorine at $2 \mathrm{~kb}$ and $800^{\circ} \mathrm{C}$, fluorine would partition in favour of the aqueous fluids.

- Calculate REE partition coefficient $\left(k_{p}^{R E F}\right)$ between aqueous fluid phase and granite melt, according to the experimental results by $[6,9]$; the values of $k_{p}^{R E E}$ are proportional to the cubic power of the chlorine molarity of the aqueous fluid, except for europium that is to the fifth power. The mathematic relationship of REE partition coefficients and the chlorine molarity of aqueous fluids can be obtained, based on a least square regression analysis of the experimental data by $[6,9]$ as follows.

The REE partition coefficients ( $k_{p}^{R E E}$ ) data used for the least square regression analysis were acquired under the conditions of $4.0 \mathrm{~kb}, 800^{\circ} \mathrm{C}$, and QFM (quartz-fayalite-magnetite) buffer by [6], and the data were obtained at $2.0 \mathrm{~kb}$ and $800^{\circ} \mathrm{C}$ in the experiments in [9]. Although the effect of temperature on the partition coefficients is not well defined in these experiments, the pressure effect is remarkable, showing that the partition coefficients of the trivalent REE increase with decreasing pressure. Therefore, the volatile phase exsolved from granite melts at 


$$
\begin{array}{ll}
k_{p}^{L a}=0.0408\left(m_{C l}^{m}\right)^{3}-0.0116 & \left(\mathrm{R}^{2}=0.95, \mathrm{n}=13\right) \\
k_{p}^{C e}=0.0394\left(m_{c l}^{m}\right)^{3}+0.0068 & \left(\mathrm{R}^{2}=0.94, \mathrm{n}=18\right) \\
k_{p}^{N d}=0.0396\left(m_{C l}^{m}\right)^{3}-0.0176 & \left(\mathrm{R}^{2}=0.94, \mathrm{n}=13\right) \\
k_{p}^{S m}=0.0324\left(m_{C l}^{m}\right)^{3}-0.0118 & \left(\mathrm{R}^{2}=0.92, \mathrm{n}=13\right) \\
k_{p}^{E u}=0.0015\left(m_{C l}^{m}\right)^{5}+0.0891 & \left(\mathrm{R}^{2}=0.95, \mathrm{n}=18\right) \\
k_{p}^{G d}=0.0275\left(m_{C l}^{m}\right)^{3}+0.0052 & \left(\mathrm{R}^{2}=0.92, \mathrm{n}=20\right) \\
k_{p}^{T b}=0.0247\left(m_{C l}^{m}\right)^{3}-0.0072 & \left(\mathrm{R}^{2}=0.92, \mathrm{n}=13\right) \\
k_{p}^{H o}=0.0190\left(m_{C l}^{m}\right)^{3}-0.0024 & \left(\mathrm{R}^{2}=0.92, \mathrm{n}=13\right) \\
k_{p}^{Y b}=0.02275\left(m_{c l}^{m}\right)^{3}+0.0116 & \left(\mathrm{R}^{2}=0.92, \mathrm{n}=18\right) \\
k_{p}^{L u}=0.0105\left(m_{C l}^{m}\right)^{3}+0.0025 & \left(\mathrm{R}^{2}=0.90, \mathrm{n}=13\right)
\end{array}
$$

pressures below $4 \mathrm{~kb}$ may contain higher REE concentration than those calculated using the eqs. 3 to 12. The limitation of this type of modelling should be noted. Clearly, more experiments are required to cover a range of pressures at least from lower to upper crust.

- $\quad$ Calculate the REE concentration of MVP on the basis of the $k_{p}^{R E E}$ values calculated described above. For example, Ce content in the MVP equals to $k_{p}^{C e} \times C e$ content in the melt, given that $\mathrm{Ce}$ content in the sample (granite sample) equals to Ce content in the granite melt (Table 1).

- $\quad$ Plot the REE data of the MVPs in equilibrium with the granite melt as a commonly-used REE pattern; here, using REE values in the fresh granite as the normalization values rather than chondrite, in order to illustrate REE fractionation between the aqueous vapour phase and granite melt (Fig. 2).

- $\quad$ Compare the REE patterns of mineralized or altered rocks host to gold mineralization to those of the calculated aqueous vapour phase to trace the source of ore fluids (Fig. 3).

\section{APPLICATION}

To illustrate the utility and applicability of the procedure as described above, it is applied to the Lake George Sb-AuW-Mo mineral deposit, New Brunswick (Canada), which was the largest antimony producer in North America until mid-1990s. This deposit is temporally and spatially associated with the Early Devonian Lake George granodiorite stock [14-20]. The occurrence of Au-bearing quartz-carbonate veinlets and stockworks associated with W-Mo mineralization within the granodiorite stock, quartz- feldspar dyke, and the proximal metamorphic aureole strongly suggests that associated Au mineralization is related to the hydrothermal system associated with this hypabyssal intrusion [15-17, 19], analogous to intrusion-related gold systems [13, 20-24].

Table 1 presents the procedures for calculating REE concentrations in magmatic volatile phases described above using the Lake George granodiorite as an example. Table $\mathbf{2}$ lists the REE concentrations in the Lake George granodiorite [17], mineralized quartz-feldspar porphyry [19], and magmatic volatile phases at chlorine molarity of $m_{C l}^{v}=1.23$ and 2.56 $M$ in MVPs calculated in terms of the procedures described above, based on the granodiorite chlorite content and the salinity of primary fluid inclusions trapped in apatite enclosed in a plagioclase crystal fluid [13], respectively.

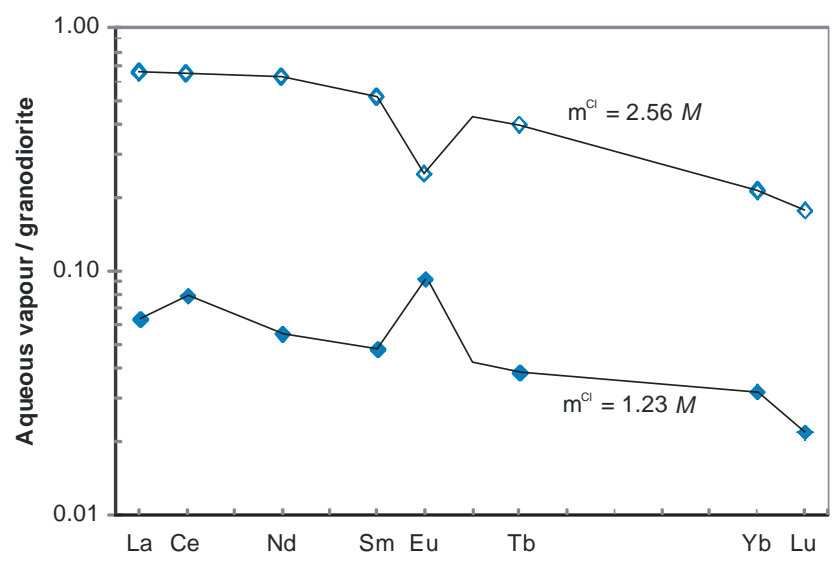

Fig. (2). Granodiorite-normalized REE patterns of magmatic fluids that have chlorine molarity of $m_{C l}^{v}=1.23 M$ and $2.56 M$ (see text for detailed calculation). The normalization values in Table $\mathbf{1}$. 


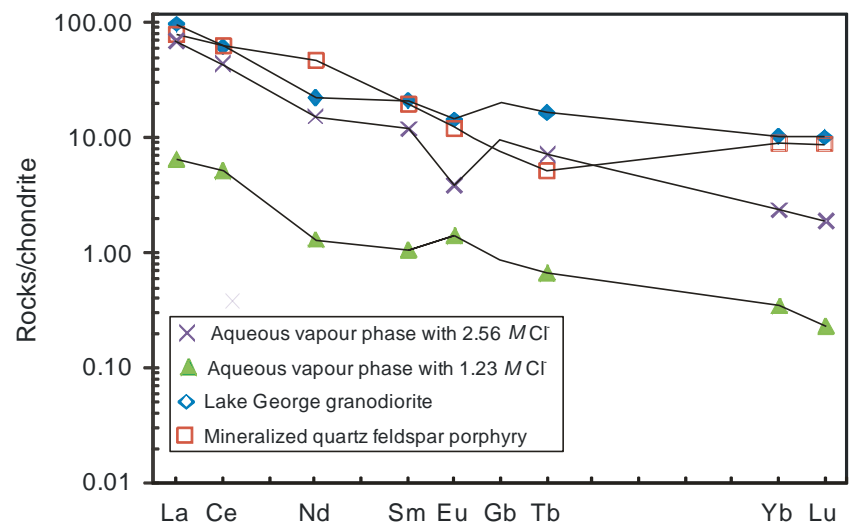

Fig. (3). Chondrite-normalized REE patterns of the Lake George granodiorite (data from [17]) and mineralized quartz-feldspar porphyry (Data from [19]), comparing with the REE patterns of MVPs. The chondite values from Boynton [28].

Table 2. REE Concentrations (ppm)

\begin{tabular}{|c|c|c|c|c|}
\hline & $\mathbf{1}$ & $\mathbf{2}$ & $\mathbf{3}$ & $\mathbf{4}$ \\
\hline \hline $\mathrm{La}$ & 31 & 25 & 1.97 & 20.89 \\
\hline $\mathrm{Ce}$ & 51 & 52 & 4.07 & 34.36 \\
\hline $\mathrm{Nd}$ & 13.7 & 29 & 0.76 & 8.90 \\
\hline $\mathrm{Sm}$ & 4.2 & 3.9 & 0.20 & 2.24 \\
\hline $\mathrm{Eu}$ & 1.1 & 0.9 & 0.10 & 0.28 \\
\hline $\mathrm{Tb}$ & 0.8 & 0.25 & 0.03 & 0.33 \\
\hline $\mathrm{Yb}$ & 2.2 & 1.9 & 0.07 & 0.48 \\
\hline $\mathrm{Lu}$ & 0.3 & 0.29 & 0.01 & 0.06 \\
\hline
\end{tabular}

Fig. (2) shows the calculated REE patterns in MVPs at $m_{C l}^{v}=1.23$ and $2.56 \mathrm{M}$, normalized by the Lake George granodiorite. With increasing value of $m_{C l}^{v}$, REE concentrations in the respective MVPs increase significantly (Table 1). At $m_{C l}^{v}=1.23 \mathrm{M}$, the REE pattern of MVP displays a positive $\mathrm{Eu}$ anomaly, whereas at $m_{C l}^{v}=2.56 \mathrm{M}$ the pattern show a pronounced negative anomaly.

When a comparison with the Lake George granodiorite and mineralized and altered quartz-feldspar porphyry is made, intriguing information stands out that these MVPs appear to decouple with the granodiorite that is roughly similar to the altered porphyry, except the latter lacks a Eu anomaly (Fig. 3). This may result from interaction of MPVs with the quartz-feldspar porphyry, leading to the disappearance of $\mathrm{Eu}$ anomaly and in some of the REE portion intersecting with that of the granodiorite. This also suggests that hydrothermal fluid(s) causing alteration as well as mineralization (sericite; see [19]), and gold mineralization are derived from the progressively cooling voluminous magma. This interpretation is supported by the prior studies of fluid inclusion, mineral chemistry, stable isotopes, and lithogeochemistry [13, 20, 22-24].

\section{DISCUSSION}

Although the experimental data on REE partitioning between MVPs and granite melt published are very limited and incomplete, implications for calculating REE patterns in MVPs used for tracing magmatic fluids are encouraging. This technique is relatively cheap compared to stable isotopes, and can be used as a tool to investigate the metallogeny of mineral deposits associated with granitoid intrusions.

A few problems are noted when using REE patterns of MVPs calculated in terms of partition coefficients to study of fluid source(s) forming a mineral deposit. First, eqs. 3 to 12 may be only applied to the conditions defined in (or similar to) the experiments $[6,9]$, although the pressure effect may be inferred to some extent. Secondly, the experimental values of REE partition coefficient ( $k_{p}^{R E E}$ ) are considered to be controlled only by the chlorine concentrations of aqueous fluids in these experiments. The other chemical components, such as $\mathrm{CO}_{3}^{2-}, \mathrm{HS}^{-}$, have not been studied on the control of $k_{p}^{R E E}[6,9]$. Thirdly, it is hard to estimate the chlorine molarity $\left(m_{C l}^{m}\right)$ of granite melt as pointed out by [10], as chorine is readily lost. Using the salinity of primary fluid inclusions trapped in apatite enclosed in plagioclase as shown in the Lake George granodiorite (Fig. 1; [13]) may be a quick solution to this problem (i.e., estimate of chlorine molarity of magmatic fluid; see Step 2 above). Also, the methods proposed by [4] may offer an estimation of chlorine molarity $\left(m_{C l}^{m}\right)$ of granite melt.

Another issue arises in tracking the source(s) of ore materials including metals (e.g., $\mathrm{Au}, \mathrm{Cu}, \mathrm{S})$ and fluids $\left(\mathrm{H}_{2} \mathrm{O}\right)$. A use of the estimated abundance data of REE in MVPs presented in this contribution means that both REE and $\mathrm{H}_{2} \mathrm{O}$ are derived from the cooling granite magma(s), but does not provide for evidence for the source of $\mathrm{Au}, \mathrm{Cu}$, and $\mathrm{S}$. Sulphur isotopes in conjunction with fluid inclusions may better constrain sulphur source in the study of the Lake George deposit $[13,20]$. It is known that magmatic pyrrhotite is present in the Lake George granodiorite, suggesting that most of the $\mathrm{Au}$ and $\mathrm{Cu}$ partitions into early sulphide liquid because their partition coefficients between sulphide and granite melt are very high. In such a case, MVPs must have low contents of $\mathrm{Au}$ and $\mathrm{Cu}$, thus the potential of forming a gold deposit via simple melt-volatile partitioning could be low, as those metals were sequestered by earlier sulphide liquation processes. However, it is also well known that the primary magmatic sulphide minerals are not stable when interacting with MPVs releasing from progressively cooling, voluminous and volatile-saturated magma(s)/intrusion at depth. Resorption, oxidization, and destructions of these liquidation sulphides could liberate $\mathrm{Au}$, $\mathrm{Cu}$, and $\mathrm{S}$, and enhance the metalliferous endowment of the magmatic fluids [22, 25-27], which may then precipitate ore metals in a suitable setting, such as shear zone, hydrofracture system, to generate an intrusion-related gold deposit; the Lake George deposit is an example of such a process. 
In conclusion, the similarities of the mineralized rocks and the calculated nagmatic fluids in REE patterns suggest that the ore-forming fluids are derived dominantly from the granodiorite, providing evidence that origin of the Lake George Sb-Au-W-Mo mineral deposit is analogous to an intrusion-related gold system.

\section{ACKNOWLEDGEMENTS}

Constructive reviews of the manuscript by Prof. Dave Lentz and Prof. Guoxiang Chi are gratefully acknowledged, which greatly improved the manuscript. I thank Dr. Sean H. McClenaghan for his comments on the earlier draft of the manuscript.

\section{CONFLICT OF INTEREST}

Declared none.

\section{REFERENCES}

[1] Holland HD. Granites, solutions, and base metal deposits. Econ Geol 1972; 67: 281-301

[2] Candela PA. Theoretical constraints on the chemistry of the magmatic aqueous phase. In: Stein HJ, Hannah JL, Eds. Orebearing granite systems; petrogenesis and mineralizing processes. Geological Society of America Special Paper 246, 1990; pp. 11-20.

[3] Candela PA, Piccoli PM. Magmatic contributions to hydrothermal ore deposits: an algorithm (MVPart) for calculating the composition of the magmatic volatile phase. Rev Econ Geol 1998; 10: 97-108.

[4] Piccoli PM, Candela PA, Williams TJ. Estimation of aqueous $\mathrm{HCl}$ and $\mathrm{Cl}$ concentrations in felsic systems. Lithos 1999; 46: 591-604.

[5] Kilinc IA, Burnham CW. Partitioning of chloride between silicate melt and coexisting aqueous phase from 2 to 8 kilobars. Econ Geol 1972; 67: 231-5.

[6] Flynn R, Burnham CW. An experimental determination of rare earth partition coefficients between a chlorite containing vapour phase and silicate melts. Geochim Cosmochica Acta 1978; 42: 685701.

[7] Webster JD, Holloway JR. Partitioning of $\mathrm{F}$ and $\mathrm{Cl}$ between magmatic hydrothermal fluids and highly evolved granitic magmas. In: Stein HJ, Hannah JL, Eds. Ore-bearing granite systems; petrogenesis and mineralizing processes. Geological Society of America Special Paper 246, 1990; pp. 21-34.

[8] Webster JD, De Vivo B. Experimental and modeled solubilities of chlorine in aluminosilicate melts, consequences of magma evolution, and implications for exsolution of hydrous chloride melt at Mt. Somma-Vesuvius. Am Mineralogist 2002; 87: 104-61.

[9] Reed MJ, Candela PA, Piccoli PM. The distribution of rare earth elements between monzogranitic melt and the aqueous volatile phase in experimental investigations at $800^{\circ} \mathrm{C}$ and $200 \mathrm{MPa}$. Contribo Mineral Petrol 2000; 140: 251-62.

[10] London D. Estimating abundances of volatile and other mobile components in evolved silicic melts through mineral-melt equilibria. J Petrol 1997; 38: 1691-706.

[11] Webster JD, Holloway JR. Experimental constraints on the partitioning of $\mathrm{Cl}$ between topaz rhyolite melt and $\mathrm{H}_{2} \mathrm{O}$ and $\mathrm{H}_{2} \mathrm{O}+$
$\mathrm{CO}_{2}$ fluids: new implications for granitic differentiation and ore deposition. Geochim Cosmochim Acta 1989; 51: 2091-107.

[12] Webster JD, Holloway JR, Hervig RL. Partitioning of lithophile trace elements between $\mathrm{H}_{2} \mathrm{O}$ and $\mathrm{H}_{2} \mathrm{O}+\mathrm{CO}_{2}$ fluids and topaz rhyolite melt. Econ Geol 1989; 84: 116-4.

[13] Yang XM, Lentz DR, Chi G, Kyser TK. Fluid-mineral reaction in the Lake George granodiorite, New Brunswick: implications for Au-W-Mo-Sb mineralization. Can Mineralogist 2004; 42: 1443-64.

[14] Seal RR II, Clark AH, Morrissy CJ. Stockwork tungsten (scheelite)-molybdenum mineralization, Lake George, southwestern New Brunswick. Econ Geol 1987; 82: 1259-82.

[15] Seal RR II, Clark AH, Morrissy CJ. Lake George, southwestern New Brunswick: a Silurian, multi-stage, polymetallic (Sb-W-MoAu-base metal) hydrothermal centre. In: Taylor RP, Strong DF, Eds. Recent advances in the geology of granite-related mineral deposits. Can Inst Mining Metallurgy 1988; 39: 252-64.

[16] Lentz DR, Thorne KG, Yang XM. Preliminary analysis of the controls on the various episodes of gold mineralization at the Lake George antimony deposit, New Brunswick. In: Carroll BMW, Ed. Current Research 2002 New Brunswick Department of Natural Resources and Energy Division, Mineral Resource Report 02-1, 2002; pp. 55-79.

[17] Yang XM, Lentz DR, Chi G. Petrochemistry of Lake George granodiorite stock and related gold mineralization, York County, New Brunswick. Geological Survey of Canada. Curr Res 2002; 2002-D7: 1-10.

[18] McLeod MJ, Johnson SC, Krogh TE. Archived U-Pb (zircon) dates from southern New Brunswick. Atlantic Geol 2003; 39: 209-25.

[19] Leonard PRR, Lentz DR, Poujol M. Petrology, geochemistry, and $\mathrm{U}-\mathrm{Pb}$ (zircon) age of the quartz-feldspar porphyry dyke at the Lake George antimony mine, New Brunswick: implications for origin, emplacement process, and mineralization. Atlantic Geol 2006; 42: 13-29.

[20] Yang XM, Lentz DR. Sulfur isotopic systematics of granitoids from southwestern New Brunswick, Canada: Implications for magmatic-hydrothermal processes, redox conditions, and gold mineralization. Mineralium Deposita 2010; 45: 795-816.

[22] Yang XM, Lentz DR, Sylvester PJ. Gold contents of sulphide minerals in granitoids from southwestern New Brunswick, Canada. Mineralium Deposita 2006; 41: 369-386.

[23] Yang XM, Lentz DR, Chi G, Thorne KG. Geochemical characteristics of gold-related granitoids in southwestern New Brunswick, Canada. Lithos 2008; 104: 355-77.

[24] Yang XM, Lentz DR. Chemical composition of rock-forming minerals in gold-related granitoid intrusions, southwestern New Brunswick, Canada: Implications for crystallization conditions, volatile exsolution and fluorine-chlorine activity. Contrib Mineral Petrol 2005; 150: 287-305

[25] Keith JD, Whitney JA, Hattori K, et al. The role of magmatic sulphides and mafic alkaline magmas in the Bingham and Tintic mining districts, Utah. J Petrol 1997; 38: 1679-90.

[26] Halter WE, Heinrich CA, Pettke T. Magma evolution and formation of porphyry $\mathrm{Cu}-\mathrm{Au}$ ore fluids: Evidence from silicate and sulphide melt inclusions. Mineralium Deposita 2005; 39: 84563.

[27] Stavast WJA, Keith JD, Christiansen EH, et al. The fate of magmatic sulfides during intrusion or eruption, Bingham and Tintic Districts, Utah. Econ Geol 2006; 101: 329-45.

[28] Boynton WV. Geochemistry of the rare earth elements: meteorite studies. In: Henderson, P, Ed. Rare earth element geochemistry. Amsterdam: Elsevier 1984; pp. 63-114.

This is an open access article licensed under the terms of the Creative Commons Attribution Non-Commercial License (http://creativecommons.org/licenses/by$\mathrm{nc} / 3.0 /$ ) which permits unrestricted, non-commercial use, distribution and reproduction in any medium, provided the work is properly cited. 